\title{
Use of Prolactin Receptor Antagonist to Better Understand Prolactin Regulation of Pituitary Homeostasis
}

\author{
Jimena Ferraris $^{a}$ Sophie Bernichtein ${ }^{b}$ Daniel Pisera ${ }^{a}$ Vincent Goffin ${ }^{b}$ \\ a Institute of Biomedical Research, School of Medicine, University of Buenos Aires-CONICET, \\ Buenos Aires, Argentina; ${ }^{b}$ Inserm, Unit 845, Research Center Growth and Signaling, Prolactin/Growth Hormone \\ Pathophysiology Laboratory, University Paris Descartes, Sorbonne Paris Cité, Faculty of Medicine, Necker Site, \\ Paris, France
}

\section{Key Words}

Prolactin · Del1-9-G129R-hPRL · Prolactin receptor

antagonist $\cdot$ Pituitary $\cdot$ Apoptosis $\cdot$ Proliferation

\begin{abstract}
The anterior pituitary is permanently regulated by processes of apoptosis and proliferation in order to maintain tissue homeostasis. Several factors have been implicated in this regulation and lately, prolactin (PRL) has been included into that list. However, since PRL is secreted by anterior pituitary lactotropes, the actual outcome of its autocrine/paracrine actions on pituitary cells has remained difficult to assess. The availability of the pure PRL receptor antagonist Del1-9G129R-hPRL has been helpful to circumvent this problem. While PRL has been traditionally associated with increased cell proliferation, recent studies revealed that this hormone actually induces apoptosis and decreases proliferation of anterior pituitary cells, by mechanisms involving the PRL receptor. The aim of this short review is to overview our current understanding of the regulation of pituitary homeostasis by PRL. Moreover, studies involving Del1-9-G129R-hPRL have helped anticipate to what extent future treatments involving PRL receptor inhibitors may interfere with processes regulated by PRL at the central level.

(c) 2013 S. Karger AG, Basel
\end{abstract}

\section{Development of Prolactin Receptor Antagonists}

Prolactin (PRL) was identified in the late 1920s as a hormone produced in the anterior pituitary and able to stimulate milk synthesis by the mammary gland $[1,2]$. It was later shown that PRL production/secretion by the pituitary was mainly under the inhibitory control of dopamine, acting via the dopamine 2 receptor (D2R) expressed in lactotrope cells (for a review, see Freeman et al. [3]). This discovery paved the way for the development of dopamine agonists now used routinely as therapeutic inhibitors of PRL secretion in patients exhibiting pathological hyperprolactinemia [4]. Besides endocrine PRL, local PRL production has been documented in various tissues referred to as extrapituitary sites of PRL production, where the hormone is assumed to act in an autocrine/ paracrine manner (for a review, see Ben-Jonathan et al. [5]). These include the breast, the prostate, the skin or cells of the immune system to cite only a few. Interestingly enough, various studies reported that the level of PRL protein expression was enhanced in tumors affecting some of these tissues, e.g. breast and prostate tumors [6, 7]. Based on its ability to stimulate proliferation of various cell types [8-10], it was then suggested that such an increased PRL expression may participate in the promo-

\section{KARGER}

E-Mail karger@karger.com

www.karger.com/nen
(C) 2013 S. Karger AG, Basel

0028-3835/13/0983-0171\$38.00/0
Vincent Goffin

Inserm U845, Centre de Recherche Croissance et Signalisation

Equipe 'Physiopathologie des Hormones PRL/GH', Faculté de Medecine Paris Descartes Batiment Leriche - Porte 9, 96 rue Didot, CS 61431, FR-75993 Paris Cedex 14 (France)

E-Mail vincent.goffin@inserm.fr 
tion of tumor growth. However, since the regulation of PRL gene expression in extrapituitary tissues is virtually unknown, this hypothesis could not be addressed using pharmacological inhibitors able to block PRL expression in peripheral tumors. This was the rationale to develop PRL receptor (PRLR) antagonists aimed to block PRL biological actions at the level of the receptor when PRL expression cannot be targeted [6].

The PRLR belongs to the cytokine receptor superfamily, which involves non-tyrosine kinase, single-pass transmembrane chains [11]. Prolactin receptor signaling is triggered by the formation of a heterotrimeric complex involving one ligand bound to two identical receptor moieties forming a homodimer (fig. 1a). This ternary complex involves 3 intermolecular interactions called sites 1 and 2 (between PRL and each receptor) and site 3 (between the two receptors) [12]. The active complex then triggers various intracellular signaling cascades including the canonical Jak2/STAT5 pathway, MAPK, Akt and Src cascades (for a review, see Goffin et al. [6]). Similar to the development of the growth hormone receptor antagonist Somavert [13], the rational design of competitive PRLR antagonists reported by various teams has generally involved the introduction of appropriate mutations at binding site 2 , which results in the functional inhibition of the interaction between PRL and one of the two receptor moieties (for a review, see Goffin et al. [14]) (fig. 1a). The lead compound that we have developed is called Del1-9-G129R-hPRL, due to the truncation of the $9 \mathrm{~N}$-terminal residues and the steric hindrance introduced at position 129 (Arg substituted for Gly) [15]. The antagonistic properties of Del1-9-G129R-hPRL have been assessed by us and several collaborators using a wide panel of in vitro and in vivo assays, involving various cell types (breast, prostate, skin, neural cells, etc.) of mouse, rat or human origin [16-21]. Using pharmacological approaches to achieve acute inhibition of PRLR signaling, these studies have shown that (1) Del1-9-G129R-hPRL is devoid of residual agonism, (2) efficiently competes with exogenous PRL when added in $>10$-fold molar excess to compensate for its lower affinity for the PRLR, and (3) partially inhibits the actions triggered by autocrine PRL when added in high excess (at undetermined fold since in extrapituitary tissues locally produced PRL is frequently below detection limits). Due to the short half-life of the antagonist, we turned to a transgenic approach to evaluate its long-term effects in vivo. Transgenic mice expressing Del1-9-G129R-hPRL systemically (called below Tg Del1-9-G129R mice) did not display gross pathological phenotypes. We noticed that 6-month-old females had irregular reproductive cycles which tended to normalize with age [unpubl. data] but this did not significantly alter fertility. Since female mice deficient for the PRLR gene (PRLR-KO) are infertile [22], the absence of a marked reproductive phenotype of Tg ${ }^{\text {Del1-9-G129R }}$ females indicated that total inhibition of PRLR signaling was not achieved in these animals, as would have been expected from a competitive antagonist. This transgenic model also revealed the antitumor (antiproliferative) activity of the PRLR antagonist in the context of autocrine PRL-induced prostate tumors [23] (fig. 1b). This is to our knowledge the first molecule that has been shown to functionally counteract the actions triggered by locally produced PRL.

The effects of PRLR antagonists on various peripheral PRL target cell types/tissues as well as their potential therapeutic use as tumor growth inhibitors have been widely discussed in recent review articles $[6,7,24]$; therefore, these issues will not be considered hereafter. One of the open questions in the above context is to what extent future treatment involving PRLR signaling inhibitors may interfere with processes regulated by PRL at the central level, including PRL production per se. This question is particularly relevant since many of the feedback mechanisms regulating pituitary PRL production remain poorly understood. In contrast to other pituitary hormones that are regulated by identified peripheral secondary messenger(s), e.g. insulin-like growth factor-1, one of the major downregulators of pituitary GH secretion, such a putative factor has not yet been identified for the PRL system. Thus, the aim of this short review is to overview our current understanding of the feedback mechanisms by which PRL controls its own production and, more generally, regulates pituitary homeostasis, and to highlight, where appropriate, the added value of PRLR antagonists in advancing our knowledge.

\section{Prolactin Actions in the Hypothalamus}

Physiological adaptations to pregnancy and lactation induced by PRL involve its action at the level of the central nervous system (CNS). Prolactin acts in the forebrain subventricular zone inducing the production of neuronal progenitors that migrate to the olfactory bulb [25]. In pregnant females, this process is essential to appropriate behavioral adaptive changes in the postpartum period, required for normal offspring development (reviewed in Larsen and Grattan [26]).

In addition, PRL regulates the hypothalamic-pituitary-gonadal axis. The anovulatory effect of hyperpro- 

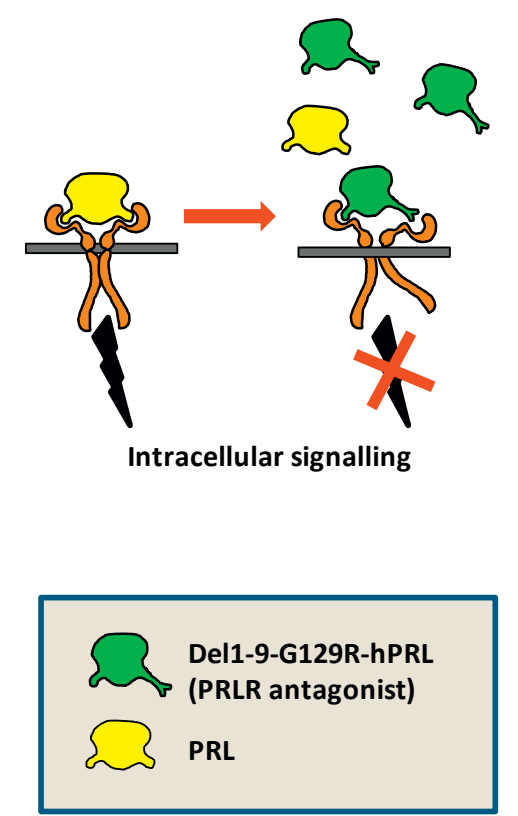

b

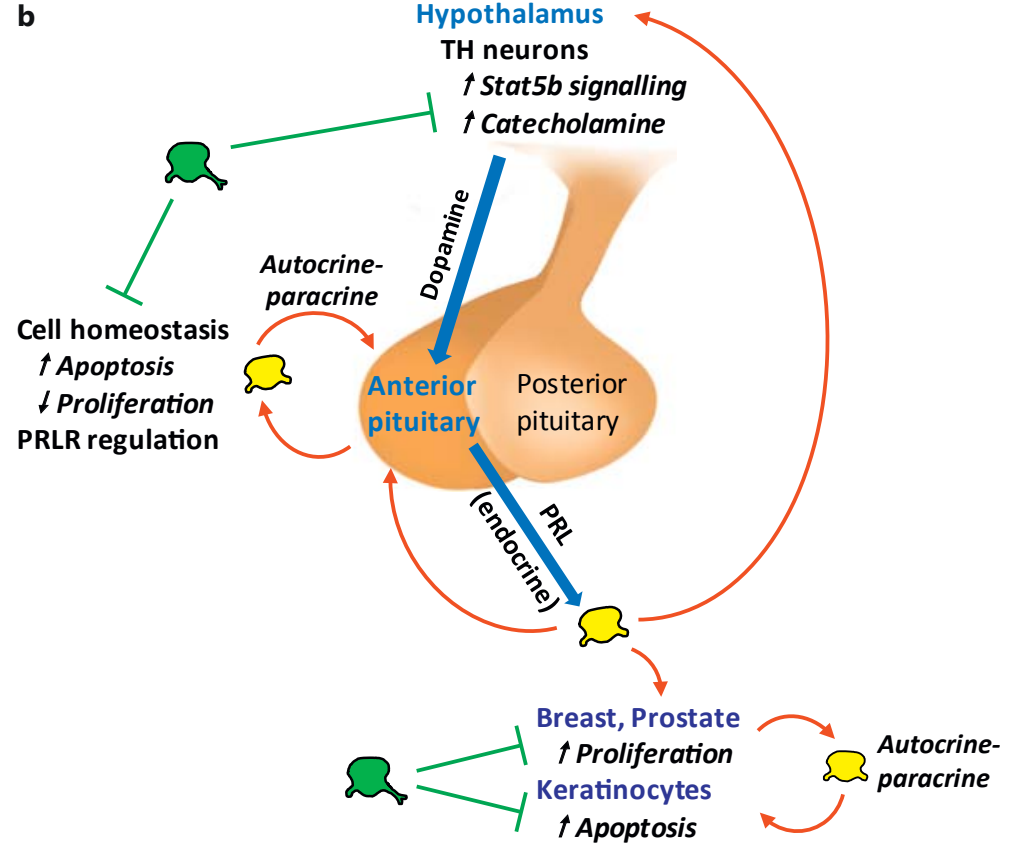

Fig. 1. a Mechanism of action of PRLR antagonist. Prolactin binds to a PRLR homodimer which results in the activation of intracellular signaling. PRLR antagonists (e.g. Del1-9-G129R-hPRL) are sterically mutated at site 2 , which prevents functional interaction with the PRLR; hence, they act as competitive antagonists in the presence of PRL. b Simplified representation of PRL actions that have been shown to be inhibited by Del1-9-G129R-hPRL antago- nist at the central and peripheral levels. PRL acts on hypothalamic TH neurons (feedback) and on pituitary cells (autocrine/paracrine) to regulate PRL production and pituitary homeostasis. Breast, prostate and keratinocytes are given as three examples of peripheral target tissues/cells regulated by circulating and/or autocrine/paracrine PRL (see text for details). lactinemia is due, at least in part, to the inhibition of the release of hypothalamic gonadotrophin-releasing hormone mediated by PRL. Recently, it was reported that this property of PRL involves the inhibition of kisspeptin neurons, the major regulators of gonadotrophin-releasing hormone release, which express the PRLR [27].

Prolactin also controls its own pituitary secretion by acting at the hypothalamic level. Although PRL is expressed in the CNS, mainly in hypothalamic neurons [5], Larsen and Grattan [28] demonstrated that inhibition of pituitary PRL secretion by bromocriptine increased postpartum anxiety and impaired maternal behavior, and that subcutaneous PRL administration restored the normal maternal behavioral patterns. In fact, PRL enters the brain via the choroid plexus by a PRLRmediated mechanism, and it was shown that the expression of PRLR in choroid plexus increased during lactation [29]. These observations suggest that PRL effects at the CNS level are mainly exerted by PRL secreted by the pituitary gland.

Oxytocin acts as a PRL-releasing peptide under some physiological conditions [30] and PRL inhibits the activity of paraventricular oxytocinergic neurons, suggesting the existence of an inhibitory feedback loop [31]. Cervical stimulation leads to two daily surges of PRL secretion, via pelvic nerve afference [32] to the CNS. The signal is then transmitted via noradrenergic neurons in the locus coeruleus to the hypothalamic paraventricular nucleus [33], which leads to an increase in oxytocin release that finally stimulates PRL secretion [30]. Then, PRL inhibits the activity of oxytocin-releasing neurons in the paraventricular nucleus [31], completing a negative feedback loop. However, the most documented action of PRL in the hypothalamus involves the control of dopaminergic neurons in the arcuate nucleus. Under physiological conditions, anterior pituitary PRL release is tonically inhibited 
by dopaminergic signals originating from the hypothalamus [34]. Prolactin thus participates in a short negative feedback loop by stimulating the activity of hypothalamic neuroedocrine dopaminergic neurons, and increasing dopamine release (for a review, see Freeman et al. [3]). The hypothalamus expresses the PRLR [35-37], and it was demonstrated using in vitro cell culture preparations of the fetal rat mediobasal hypothalamus that PRL stimulation induces expression and activity of tyrosine hydroxylase $(\mathrm{TH})$ [38], the rate-limiting enzyme in catecholamine synthesis which in vivo eventually increases dopamine input into the anterior pituitary. The effect of PRL on hypothalamic catecholamine synthesis was significantly reduced using a 10-fold excess of Del1-9G129R-hPRL, indicating that this action is PRLR-specific (fig. 1b) [38]. The latter study provided evidence for the usefulness of this antagonist as a molecular tool to investigate further the biological effects and mechanisms of action of PRL on hypothalamic neurons. It was next demonstrated that STAT5B was the primary mediator of PRL actions in TH-positive cells from the mediobasal fetal rat hypothalamus [39, 40] and mouse hypothalamus [40]. The involvement of STAT5B was unexpected since PRLR preferentially signals via STAT5A. Interestingly enough, although Del1-9-G129R-hPRL significantly inhibited STAT5 phosphorylation induced by PRL in TH-positive neurons, $\sim 20 \%$ of cells remained positive for nuclear (active) STAT5 even at extremely high antagonist concentration $(>100 \mu \mathrm{M})$. Since these studies confirmed that Del1-9-G129R-hPRL was devoid of residual agonistic activity towards the rat PRLR even at these concentrations, this observation suggested that some TH-positive neurons may exhibit very high sensitivity to low PRL concentrations and/or resistance to PRLR signaling inhibitors [39]. This may account for the absence of detectable hyperprolactinemia in $\mathrm{Tg}^{\text {Del1-9-G129R }}$ mice [23] despite the clear inhibitory action of the PRLR antagonist on dopamine synthesis as demonstrated in these in vitro studies.

\section{Prolactin Actions in the Pituitary}

In the majority of its target tissues, most of the documented effects of PRL on cell renewal relate to the stimulation of cell proliferation (for reviews, see [3, 41, 42]). Nevertheless, PRL has also been shown to exert antiproliferative/proapoptotic actions in some specific tissues, and we and others have identified that the pituitary falls into this second category. Typical examples of these opposite effects on cell renewal are given below.

\section{Prolactin, Proliferation and Apoptosis}

Prolactin stimulates proliferation of mammary gland epithelium [43], hepatocytes [44], pancreatic beta cells [45], prostate epithelial cells [23], astrocytes [46], neurons [25] and various cells of the immune system [47]. Many of these actions are associated with adaptation to litter care, e.g. lactation and maternal behavior. Mammary gland development during pregnancy depends mainly on PRL action that induces proliferation and differentiation of the secretory epithelium, especially during lobuloalveolar differentiation [22]. After lactation, the mammary gland undergoes involution which involves cellular apoptosis induced by various signals, including a decrease in PRL-induced JAK/STAT signaling [48]. Prolactin contributes to maternal behavior by stimulating proliferation of neural stem cells in the forebrain subventricular zone, which in turn leads to increased numbers of neurons in the olfactory bulbs [25]. These actions of PRL on neurogenesis and maternal behavior have been recently reviewed by Grattan's group [26]. In the pancreas, PRL is responsible for beta cell proliferation, allowing normal glucose homeostasis during pregnancy [45].

Prolactin also controls nonreproductive actions, as in the immune system. It regulates $\mathrm{T}$ cell differentiation, B cell-mediated tolerance and enhances proliferative responses to several mitogens and, by a PRLR-mediated effect, PRL stimulates mitosis of normal and lymphomaderived lymphocytes [49]. As a hallmark of PRL proliferative properties, the growth of PRL-dependent $\mathrm{Nb} 2$ rat lymphoma cell line has been used for three decades as the reference bioassay to measure PRL activity and concentration in biological fluids [50].

Prolactin can also induce apoptosis in many contexts, which is usually beyond the actions conventional wisdom attributes to this hormone. In the rat, the peak of circulating PRL occurring at proestrus is responsible for inducing luteolysis of the corpora lutea of the preceding cycle [5153]. Prolactin is locally synthesized and secreted by keratinocytes in the human hair follicle and via a short loop mechanism, it induces apoptosis and inhibits proliferation of these cells [54]. Chondrocyte apoptosis is needed in the process of endochondral bone formation; PRL was shown to increase this process, which is assumed to favor bone elongation in pregnant and lactating rats [55]. It was also reported that PRL increases apoptosis of a human myeloma-derived cell line [56].

The proapoptotic actions of PRL are further supported by the fact that the canonical signaling cascade of its receptor, namely Jak2/STAT5, may in some instance lead to proapoptotic responses $[3,41,42,57]$. For example, the 
induction of apoptosis by oncostatin M (another hematopoietic cytokine structurally close to PRL) in osteosarcoma cells requires functional STAT5 to regulate Bax/ Bcl-2 ratio [58]. Similarly, activation of Jak2/STAT5 pathway in rat cerebella granule neurons induces apoptosis, also by regulating the expression of Bcl-2 family proteins [59]. In fact, the ultimate effects of PRL in a given tissue depend on many parameters including the PRLR isoform(s) that is(are) expressed and the particular physiological context. As discussed below, PRL-regulated cell apoptosis is a key mechanism in pituitary homeostasis.

\section{Prolactin and Anterior Pituitary Cell Renewal}

Anterior pituitary functions are regulated by multiple signals. These involve signals originating upstream, in the hypothalamus and signals originating from downstream target organs. These messenger molecules regulate pituitary hormone secretion, but also the cellular turnover of the gland. Several factors regulate cell proliferation and apoptosis in the anterior pituitary, such as dopamine [60, $61]$, estradiol $[62,63]$, and various cytokines such as tumor necrosis factor- $\alpha$ [64], Fas ligand [65] and interleukin-6 [66].

Hormones secreted by pituitary cells may also act as local paracrine/autocrine factors, which is the case for PRL [67]. Prolactin receptors are expressed by anterior pituitary cells [68-71]; therefore, one of the primary target cells PRL meets once it is secreted are lactotropes [72]. Prolactin receptor signaling inhibits PRL synthesis at the transcriptional level in lactotrope cells, which involves specific pituitary transcription factors [73]. Also, inhibition of its own secretion $[72,74]$ and increased PRLR internalization $[75,76]$ are two other mechanisms by which PRL modulates its production, and consequently its actions at the pituitary level.

In addition to regulating its own production/secretion, PRL also regulates pituitary cell turnover. It was first proposed that, as in many tissues (see above), PRL could act as a growth factor for anterior pituitary cells $[77,78]$. Since D2R KO mice develop hyperprolactinemia, pituitary hyperplasia and, finally, pituitary adenomas, it was suggested that both the lack of dopamine inhibition and stimulation of cell proliferation induced by high circulating levels of PRL were responsible for the anterior pituitary cell growth observed in these mice [79]. However, it was later observed that PRL KO [80] and PRLR KO [81] mice also exhibited anterior pituitary hyperplasia. It was concluded that activation of PRLR signaling was not involved in promoting pituitary adenoma formation. However, double PRLR/D2R KO mice develop anterior pitu-

Prolactin Regulation of Pituitary

Homeostasis itary hyperplasia at earlier ages and prolactinomas are larger than in single KO mice. This additive effect suggests that in fact the absence of PRLR signaling may intrinsically promote pituitary tumorigenesis, independently of dopamine action [81]. In contrast, it was observed that exogenous PRL diminishes the proliferation rate of primary cultures of lactotropes prepared from D2R KO mice [81]. However, the direct effects of PRL in anterior pituitary cells, especially lactotropes, are usually difficult to assess unequivocally since the stimulus (i.e. $\mathrm{PRL}$ ) is intrinsically present in the system [73]. Although pituitary PRL can be controlled with dopamine analogs, the latter intrinsically affect apoptosis and proliferation in these cells [60], therefore a dopamine-independent model was needed to address such questions. We took advantage of the Del1-9-G129R-hPRL antagonist to block the actions of endogenous PRL in order to better delineate the direct (autocrine) effects of PRL on PRL-secreting cells (fig. 1b). Thanks to this unique molecular tool, we were able to show that PRL acts as a paracrine/autocrine antiproliferative and proapoptotic factor on primary cultures of male rat anterior pituitary cells, specifically but not exclusively on lactotropes [71]. These findings definitely confirmed that the pituitary hyperplasia observed in $\mathrm{D} 2 \mathrm{R} \mathrm{KO}$ mice is not generated by a PRL proliferative action as had been initially proposed [79]. Furthermore, the availability of $\mathrm{Tg}^{\text {Del1-9-G129R }}$ mice gave us the opportunity to investigate the effect of chronic blockade of PRLR signaling in mice still expressing both the PRLR and its ligand, which more closely mimics the physiological context. We observed that Del1-9-G129R-hPRL expression induced moderate pituitary hyperplasia and 15 -fold increase in the anterior pituitary proliferation index. Accordingly, the pituitary weight of TgDel1-9-G129R mice was $25 \%$ higher compared to controls; direct comparison of pituitary hypertrophy induced by functional (Tg ${ }^{\text {Dell-9-G129R }}$ ) versus genetic (PRLR KO) PRLR signaling inhibition [81] could not be made since the animals involved in the two studies were not age-matched. Taken together, these findings indicate that PRL acts as an antiproliferative factor on anterior pituitary cells.

In females, through pregnancy and lactation and during estrus, the number of anterior pituitary cells increases, mainly due to the expansion of the lactotrope population. At the end of each of these periods, apoptosis processes restore the number of cells, maintaining tissue homeostasis. In the rat, $1.5 \%$ of anterior pituitary cells are renewed daily, this turnover being higher in females than in males, and dependent on the stage of the estrous cycle [67]. In sexually mature females, hypothalamic, pituitary, 
and ovarian hormones present particular profiles of secretion that defines the endocrine environment in each stage of the estrous cycle. In the rat, these cyclic changes are reflected in anterior pituitary cell turnover: proliferation takes place mainly during estrus whereas the higher rate of apoptosis occurs at proestrus $[82,83]$. Changes in circulating levels of gonadal steroids that characterize each stage of the estrous cycle could be, at least in part, responsible for the cyclic changes in proliferation and apoptosis observed in the anterior pituitary [67]. During proestrus, when the peak of anterior pituitary cell apoptosis is observed [63], an increase in estradiol and PRLcirculating levels occurs in both rats [3] and mice [84, 85]. As PRL is a proapoptotic factor for anterior pituitary cells, we hypothesize that this hormone could be involved in the control of the changes that occur in the anterior pituitary gland at each estrous cycle. Our laboratories are currently investigating the pituitaries of PRLR KO mice and $\mathrm{Tg}{ }^{\text {Del1-9-G129R }}$ female mice to address this hypothesis.

The molecular mechanisms by which PRL exerts proapoptotic effects to regulate pituitary cell homeostasis are currently unknown. Two major isoforms of PRLR have been reported, referred to as long and short PRLR, which display only partial overlap in their intracellular signaling capacities (reviewed in Ben-Jonathan et al. [42]). In addition, since short PRLR has been reported to exert a dominant negative effect on the ability of the long isoform to activate the Jak/STAT pathway $[86,87]$, the ultimate effects of PRL depend on the PRLR isoforms expressed and on their relative ratio. Prolactin regulates expression of its own receptor in several tissues, such as hypothalamus [35-37, 88], ovary [89], brain [70], fallopian tubes [90] and pancreas [91]. Anterior pituitary cells from both mice $[71,90]$ and rats $[68,69]$ express both PRLR isoforms. In male mouse pituitary, the long PRLR is the main isoform expressed, representing about $90 \%$ of total pituitary PRLR [71]. Interestingly enough, chronic expression of Del1-9G129R-hPRL in transgenic mice leads to a 10-fold increase in long PRLR versus only a 2-fold increase of short PRLRmRNA expression, indicating that PRL regulates the expression of its receptor in an isoform-specific manner [71]. In female rats, PRLR isoform expression in the pituitary varies during the estrous cycle [69], suggesting that gonadal steroids are involved in its regulation. In prepubertal rat pituitary, the short PRLR isoform was reported to be the main isoform expressed that was further increased by PRL treatment [90]. In adult female rat pituitary, although the long PRLR isoform is the most abundant at both proestrus and diestrus, long PRLR expression increases 1.5 -fold at diestrus compared to pro- estrus [69]. Nagano and Kelly [69] proposed that PRLR expression at proestrus may be negatively regulated by the proestrus surge of PRL acting directly or indirectly at the pituitary level. In fact, ovariectomy, which decreases circulating levels of PRL, was reported to increase PRLR expression [70]. Our ongoing studies using Tg ${ }^{\text {Dell-9-G129R }}$ female mice suggest that functional blockade of PRLR signaling alters expression of anterior pituitary PRLR in both isoform-specific and estrous cycle stage-specific manner. Taken together, these studies suggest that the regulation of PRLR expression may be one of the mechanisms by which PRL controls pituitary (lactotrope) cell turnover and homeostasis, although downstream signaling pathways involved remain to be investigated.

\section{Conclusion}

In summary, PRL exerts proapoptotic and antiproliferative effects which are critical to maintain pituitary cell homeostasis. Deficiencies in PRLR signaling lead to the accumulation of anterior pituitary cells that are not removed and continue to proliferate, which results in pituitary hyperplasia. As pituitary adenomas are the most common intracranial tumors, understanding the physiology of anterior pituitary cell turnover is useful to better understand prolactinoma pathogenesis and to design new treatments. Furthermore, these studies also suggest that therapeutic inhibition of PRLR signaling in the context of peripheral tumors (e.g. breast or prostate cancer), using PRLR antagonists or blocking antibodies [92], should take into account potential side effects of such drugs on pituitary cell homeostasis.

\section{Acknowledgements}

The authors thank Paul Kelly and Charlotte Sumida for critical reading of the manuscript.

References

1 Stricker P, Grueter R: Action du lobe antérieur de l'hypophyse sur la montée laiteuse. C R Soc Biol 1928;99:1978-1980.

2 Riddle O, Bates RW, Dykshorn SW: The preparation, identification and assay of prolactin - a hormone of the anterior pituitary. Am J Physiol 1933;105:191-216.

-3 Freeman ME, Kanyicska B, Lerant A, Nagy G: Prolactin: structure, function, and regulation of secretion. Physiol Rev 2000;80:15231631. 
4 Gillam MP, Molitch ME, Lombardi G, Colao A: Advances in the treatment of prolactinomas. Endocr Rev 2006;27:485-534.

$\checkmark 5$ Ben-Jonathan N, Mershon JL, Allen DL, Steinmetz RW: Extrapituitary prolactin: distribution, regulation, functions, and clinical aspects. Endocr Rev 1996;17:639-669.

$\checkmark 6$ Goffin V, Bernichtein S, Touraine P, Kelly PA: Development and potential clinical uses of human prolactin receptor antagonists. Endocr Rev 2005;26:400-422.

7 Goffin V, Hoang DT, Bogorad RL, Nevalainen MT: Prolactin regulation of the prostate gland: a female player in a male game. Nat Rev Urol 2011;8:597-607.

$\checkmark 8$ Brockman JL, Schroeder MD, Schuler LA: PRL activates the cyclin D1 promoter via the Jak2/Stat pathway. Mol Endocrinol 2002;16: 774-784.

-9 Shiu RP, Elsholtz HP, Tanaka T, Friesen HG, Gout PW, Beer CT, Noble RL: Receptor-mediated mitogenic action of prolactin in a rat lymphoma cell line. Endocrinology 1983;113: 159-165.

10 Nevalainen MT, Valve EM, Ingleton PM, Nurmi M, Martikainen PM, Harkonen PL: Prolactin and prolactin receptors are expressed and functioning in human prostate. J Clin Invest 1997;99:618-627.

-11 Boutin JM, Jolicoeur C, Okamura H, Gagnon J, Edery M, Shirota M, Banville D, DusanterFourt I, Djiane J, Kelly PA: Cloning and expression of the rat prolactin receptor, a member of the growth hormone/prolactin receptor gene family. Cell 1988;53:69-77.

12 Broutin I, Jomain JB, Tallet E, van Agthoven J, Raynal B, Hoos S, Kragelund BB, Kelly PA, Ducruix A, England P, Goffin V: Crystal structure of an affinity-matured prolactin complexed to its dimerized receptor reveals the topology of hormone binding site 2. J Biol Chem 2010;285:8422-8433.

13 Kopchick JJ, Parkinson C, Stevens EC, Trainer PJ: Growth hormone receptor antagonists: discovery, development, and use in patients with acromegaly. Endocr Rev 2002;23:623646.

$\checkmark 14$ Goffin V, Tallet E, Jomain JB, Kelly PA: Development of prolactin receptor antagonists: same goal, different ways. Rec Pat Endocr Metab Imm Drug Disc 2007;1:41-52.

$\checkmark 15$ Bernichtein S, Kayser C, Dillner K, Moulin S, Kopchick JJ, Martial JA, Norstedt G, Isaksson O, Kelly PA, Goffin V: Development of pure prolactin receptor antagonists. J Biol Chem 2003;278:35988-35999.

16 Dagvadorj A, Collins S, Jomain JB, Abdulghani J, Karras J, Zellweger T, Li H, Nurmi M, Alanen K, Mirtti T, Visakorpi T, Bubendorf L, Goffin V, Nevalainen MT: Autocrine prolactin promotes prostate cancer cell growth via Janus kinase-2-signal transducer and activator of transcription-5a/b signaling pathway. Endocrinology 2007;148:30893101.
17 Eyal O, Jomain JB, Kessler C, Goffin V, Handwerger S: Autocrine prolactin inhibits human uterine decidualization: a novel role for prolactin. Biol Reprod 2007;76:777-783.

18 Hou L, Xu B, Mohankumar KM, Goffin V, Perry JK, Lobie PE, Liu DX: The prolactin receptor mediates HOXA1-stimulated oncogenicity in mammary carcinoma cells. Int J Oncol 2012;41:2285-2295.

19 Pathipati P, Gorba T, Scheepens A, Goffin V, Sun Y, Fraser M: Growth hormone and prolactin regulate human neural stem cell regenerative activity. Neuroscience 2011;190:409427.

20 Scotland PE, Patil M, Belugin S, Henry MA, Goffin V, Hargreaves KM, Akopian AN: Endogenous prolactin generated during peripheral inflammation contributes to thermal hyperalgesia. Eur J Neurosci 2011;34:745-754.

21 Ramot Y, Bíró T, Tiede S, Tóth BI, Langan EA, Sugawara K, Foitzik K, Ingber A, Goffin V, Langbein L, Paus R: Prolactin - a novel neuroendocrine regulator of human keratin expression in situ. FASEB J 2010;24:1768-1779.

22 Ormandy CJ, Camus A, Barra J, Damotte D, Lucas B, Buteau H, Edery M, Brousse N, Babinet C, Binart N, Kelly PA: Null mutation of the prolactin receptor gene produces multiple reproductive defects in the mouse. Genes Dev 1997;11:167-178.

23 Rouet V, Bogorad RL, Kayser C, Kessal K, Genestie C, Bardier A, Grattan DR, Kelder B, Kopchick JJ, Kelly PA, Goffin V: Local prolactin is a target to prevent expansion of basal/ stem cells in prostate tumors. Proc Natl Acad Sci USA 2010;107:15199-15204.

24 Goffin V, Touraine P, Culler MD, Kelly PA: Drug insight: prolactin-receptor antagonists, a novel approach to treatment of unresolved systemic and local hyperprolactinemia? Nat Clin Pract Endocrinol Metab 2006;2:571-581.

-25 Shingo T, Gregg C, Enwere E, Fujikawa H, Hassam R, Geary C, Cross JC, Weiss S: Pregnancy-stimulated neurogenesis in the adult female forebrain mediated by prolactin. Science 2003;299:117-120.

-26 Larsen CM, Grattan DR: Prolactin, neurogenesis, and maternal behaviors. Brain Behav Immun 2012;26:201-209.

27 Sonigo C, Bouilly J, Carre N, Tolle V, Caraty A, Tello J, Simony-Conesa FJ, Millar R, Young J, Binart N: Hyperprolactinemia-induced ovarian acyclicity is reversed by kisspeptin administration. J Clin Invest 2012;122:37913795.

28 Larsen CM, Grattan DR: Prolactin-induced mitogenesis in the subventricular zone of the maternal brain during early pregnancy is essential for normal postpartum behavioral responses in the mother. Endocrinology 2010; 151:3805-3814.

29 Hirai J, Nishita M, Nakao N, Saito TR, Tanaka M: Regulation of prolactin receptor gene expression in the rat choroid plexus via transcriptional activation of multiple first exons during postnatal development and lactation. Exp Anim 2013;62:49-56.
30 McKee DT, Poletini MO, Bertram R, Freeman ME: Oxytocin action at the lactotroph is required for prolactin surges in cervically stimulated ovariectomized rats. Endocrinology 2007;148:4649-4657.

- 31 Sirzen-Zelenskaya A, Gonzalez-Iglesias AE, Boutet de Monvel J, Bertram R, Freeman ME, Gerber U, Egli M: Prolactin induces a hyperpolarising current in rat paraventricular oxytocinergic neurones. J Neuroendocrinol 2011; 23:883-893.

32 Helena CV, Cristancho-Gordo R, GonzalezIglesias AE, Tabak J, Bertram R, Freeman ME: Systemic oxytocin induces a prolactin secretory rhythm via the pelvic nerve in ovariectomized rats. Am J Physiol Regul Integr Comp Physiol 2011;301:R676-681.

33 Poletini MO, McKee DT, Szawka RE, Bertram R, Helena CV, Freeman ME: Cervical stimulation activates $\mathrm{A} 1$ and locus coeruleus neurons that project to the paraventricular nucleus of the hypothalamus. Brain Res Bull 2012; 88:566-573.

34 Ben-Jonathan N, Neill MA, Arbogast LA, Peters LL, Hoefer MT: Dopamine in hypophysial portal blood: relationship to circulating prolactin in pregnant and lactating rats. Endocrinology 1980;106:690-696.

35 Pi XJ, Grattan DR: Increased prolactin receptor immunoreactivity in the hypothalamus of lactating rats. J Neuroendocrinol 1999;11: 693-705.

-36 Pi XJ, Grattan DR: Increased expression of both short and long forms of prolactin receptor mRNA in hypothalamic nuclei of lactating rats. J Mol Endocrinol 1999;23:13-22.

37 Pi X, Grattan DR: Expression of prolactin receptor mRNA is increased in the preoptic area of lactating rats. Endocrine 1999;11:91-98.

38 Ma FY, Grattan DR, Goffin V, Bunn SJ: Prolactin-regulated tyrosine hydroxylase activity and messenger ribonucleic acid expression in mediobasal hypothalamic cultures: the differential role of specific protein kinases. Endocrinology 2005;146:93-102.

- 39 Ma FY, Anderson GM, Gunn TD, Goffin V, Grattan DR, Bunn SJ: Prolactin specifically activates signal transducer and activator of transcription $5 \mathrm{~b}$ in neuroendocrine dopaminergic neurons. Endocrinology 2005; 146: 5112-5119.

40 Yip SH, Eguchi R, Grattan DR, Bunn SJ: Prolactin signalling in the mouse hypothalamus is primarily mediated by signal transducer and activator of transcription factor $5 \mathrm{~b}$ but not 5a. J Neuroendocrinol 2012;24:14841491.

41 Bole-Feysot C, Goffin V, Edery M, Binart N, Kelly PA: Prolactin (PRL) and its receptor: actions, signal transduction pathways and phenotypes observed in PRL receptor knockout mice. Endocr Rev 1998;19:225-268.

42 Ben-Jonathan N, LaPensee CR, LaPensee EW What can we learn from rodents about prolactin in humans? Endocr Rev 2008;29:1-41. 
-43 Clevenger CV, Furth PA, Hankinson SE, Schuler LA: The role of prolactin in mammary carcinoma. Endocr Rev 2003;24:1-27.

-44 Olazabal IM, Munoz JA, Rodriguez-Navas C, Alvarez L, Delgado-Baeza E, Garcia-Ruiz JP: Prolactin's role in the early stages of liver regeneration in rats. J Cell Physiol 2009;219: 626-633.

45 Huang C, Snider F, Cross JC: Prolactin receptor is required for normal glucose homeostasis and modulation of beta-cell mass during pregnancy. Endocrinology 2009;150:16181626.

-46 DeVito WJ, Okulicz WC, Stone S, Avakian C: Prolactin-stimulated mitogenesis of cultured astrocytes. Endocrinology 1992;130:25492556.

47 Buckley AR: Prolactin, a lymphocyte growth and survival factor. Lupus 2001;10:684-690.

-48 Maroulakou IG, Oemler W, Naber SP, Klebba I, Kuperwasser C, Tsichlis PN: Distinct roles of the three Akt isoforms in lactogenic differentiation and involution. J Cell Physiol 2008; 217:468-477

49 Shelly S, Boaz M, Orbach H: Prolactin and autoimmunity. Autoimmun Rev 2012;11:A465A470.

-50 Tanaka T, Shiu RP, Gout PW, Beer CT, Noble RL, Friesen HG: A new sensitive and specific bioassay for lactogenic hormones: measurement of prolactin and growth hormone in human serum. J Clin Endocrinol Metab 1980;51: 1058-1063.

51 Gaytan F, Bellido C, Morales C, Sanchez-Criado JE: Luteolytic effect of prolactin is dependent on the degree of differentiation of luteal cells in the rat. Biol Reprod 2001;65:433-441.

52 Gaytan F, Bellido C, Morales C, SanchezCriado JE: Cyclic changes in the responsiveness of regressing corpora lutea to the luteolytic effects of prolactin in rats. Reproduction 2001;122:411-417.

53 Bowen JM, Keyes PL: Repeated exposure to prolactin is required to induce luteal regression in the hypophysectomized rat. Biol Reprod 2000;63:1179-1184.

54 Foitzik K, Krause K, Conrad F, Nakamura M, Funk W, Paus R: Human scalp hair follicles are both a target and a source of prolactin, which serves as an autocrine and/or paracrine promoter of apoptosis-driven hair follicle regression. Am J Pathol 2006;168:748-756.

55 Seriwatanachai D, Krishnamra N, Charoenphandhu N: Chondroregulatory action of prolactin on proliferation and differentiation of mouse chondrogenic ATDC5 cells in 3-dimensional micromass cultures. Biochem Biophys Res Commun 2012;420:108-113.

56 Gadó K, Pállinger E, Kovács P, Takács E, Szilvási I, Tóth BE, Nagy G, Domján G, Falus A: Prolactin influences proliferation and apoptosis of a human IgE secreting myeloma cell line, U266. Immunol Lett 2002;82: 191-196.

57 Binart N, Bachelot A, Bouilly J: Impact of prolactin receptor isoforms on reproduction. Trends Endocrinol Metab 2010;21:362-368.
Chipoy C, Brounais B, Trichet V, Battaglia S, Berreur M, Oliver L, Juin P, Redini F, Heymann D, Blanchard F: Sensitization of osteosarcoma cells to apoptosis by oncostatin M depends on STAT5 and p53. Oncogene 2007; 26:6653-6664.

59 Stankiewicz TR, Loucks FA, Schroeder EK, Nevalainen MT, Tyler KL, Aktories K, Bouchard RJ, Linseman DA: Signal transducer and activator of transcription-5 mediates neuronal apoptosis induced by inhibition of Rac GTPase activity. J Biol Chem 2012;287: 16835-16848.

60 Radl DB, Ferraris J, Boti V, Seilicovich A, Sarkar DK, Pisera D: Dopamine-induced apoptosis of lactotropes is mediated by the short isoform of D2 receptor. PLoS One 2011; 6:e18097.

61 Radl DB, Zarate S, Jaita G, Ferraris J, Zaldivar V, Eijo G, Seilicovich A, Pisera D: Apoptosis of lactotrophs induced by D2 receptor activation is estrogen dependent. Neuroendocrinology 2008; $88: 43-52$

62 Zarate S, Jaita G, Zaldivar V, Radl DB, Eijo G, Ferraris J, Pisera D, Seilicovich A: Estrogens exert a rapid apoptotic action in anterior pituitary cells. Am J Physiol Endocrinol Metab 2009;296:E664-671.

63 Zarate S, Zaldivar V, Jaita G, Magri L, Radl D, Pisera D, Seilicovich A: Role of estrogens in anterior pituitary gland remodeling during the estrous cycle. Front Horm Res 2010;38: 25-31.

64 Candolfi M, Jaita G, Zaldivar V, Zarate S, Pisera D, Seilicovich A: Tumor necrosis factor-alpha-induced nitric oxide restrains the apoptotic response of anterior pituitary cells. Neuroendocrinology 2004;80:83-91.

65 Jaita G, Candolfi M, Zaldivar V, Zarate S, Ferrari L, Pisera D, Castro MG, Seilicovich A: Estrogens up-regulate the Fas/FasL apoptotic pathway in lactotropes. Endocrinology 2005; 146:4737-4744

66 Haedo MR, Gerez J, Fuertes M, Giacomini D, Paez-Pereda M, Labeur M, Renner U, Stalla GK, Arzt E: Regulation of pituitary function by cytokines. Horm Res 2009;72:266-274.

67 Candolfi M, Zaldivar V, Jaita G, Seilicovich A: Anterior pituitary cell renewal during the estrous cycle. Front Horm Res 2006;35:9-21.

68 Morel G, Ouhtit A, Kelly PA: Prolactin receptor immunoreactivity in rat anterior pituitary. Neuroendocrinology 1994;59:78-84.

69 Nagano M, Kelly PA: Tissue distribution and regulation of rat prolactin receptor gene expression. Quantitative analysis by polymerase chain reaction. J Biol Chem 1994;269:1333713345.

70 Nogami H, Hoshino R, Ogasawara K, Miyamoto S, Hisano S: Region-specific expression and hormonal regulation of the first exon variants of rat prolactin receptor mRNA in rat brain and anterior pituitary gland. J Neuroendocrinol 2007; 19:583-593.
1 Ferraris J, Boutillon F, Bernadet M, Seilicovich $\mathrm{A}$, Goffin V, Pisera D: Prolactin receptor antagonism in mouse anterior pituitary: effects on cell turnover and prolactin receptor expression. Am J Physiol Endocrinol Metab 2012;302:E356-E364.

72 Melmed S, Carlson HE, Briggs J, Hershman JM: Autofeedback of prolactin in cultured prolactin-secreting pituitary cells. Horm Res 1980;12:340-344.

73 Devost D, Boutin JM: Autoregulation of the rat prolactin gene in lactotrophs. Mol Cell Endocrinol 1999;158:99-109.

74 Herbert DC, Ishikawa H, Rennels EG: Evidence for the autoregulation of hormone secretion by prolactin. Endocrinology 1979; 104:97-100.

75 Swaminathan G, Varghese B, Thangavel C, Carbone CJ, Plotnikov A, Kumar KG, Jablonski EM, Clevenger CV, Goffin V, Deng L, Frank SJ, Fuchs SY: Prolactin stimulates ubiquitination, initial internalization, and degradation of its receptor via catalytic activation of Janus kinase 2. J Endocrinol 2008;196:R1-R7.

76 Djiane J, Houdebine LM, Kelly PA: Downregulation of prolactin receptors in rabbit mammary gland: differential subcellular localization. Proc Soc Exp Biol Med 1981;168: 378-381.

77 Hosojima H, Wyche JH: Prolactin control of growth and prolactin autoregulation in cultured human pituitary cells. Horm Res 1985; 21:240-245.

78 Krown KA, Wang YF, Ho TW, Kelly PA, Walker AM: Prolactin isoform 2 as an autocrine growth factor for GH3 cells. Endocrinology 1992;131:595-602.

79 Saiardi A, Bozzi Y, Baik JH, Borrelli E: Antiproliferative role of dopamine: loss of D2 receptors causes hormonal dysfunction and pituitary hyperplasia. Neuron 1997;19:115126.

80 Cruz-Soto ME, Scheiber MD, Gregerson KA, Boivin GP, Horseman ND: Pituitary tumorigenesis in prolactin gene-disrupted mice. Endocrinology 2002;143:4429-4436.

81 Schuff KG, Hentges ST, Kelly MA, Binart N, Kelly PA, Iuvone PM, Asa SL, Low MJ: Lack of prolactin receptor signaling in mice results in lactotroph proliferation and prolactinomas by dopamine-dependent and -independent mechanisms. J Clin Invest 2002;110:973-981.

82 Yin P, Arita J: Proestrous surge of gonadotropin-releasing hormone secretion inhibits apoptosis of anterior pituitary cells in cycling female rats. Neuroendocrinology 2002;76: 272-282.

83 Hashi A, Mazawa S, Kato J, Arita J: Pentobarbital anesthesia during the proestrous afternoon blocks lactotroph proliferation occurring on estrus in female rats. Endocrinology 1995; 136:4665-4671.

-84 Flurkey K, Gee DM, Sinha YN, Wisner JR, Jr, Finch CE: Age effects on luteinizing hormone, progesterone and prolactin in proestrous and acyclic C57BL/6j mice. Biol Reprod 1982;26:835-846. 
85 Michael SD: Plasma prolactin and progesterone during the estrous cycle in the mouse. Proc Soc Exp Biol Med 1976;153:254-257.

-86 Jabbour HN, Kelly PA: Prolactin receptor subtypes: a possible mode of tissue specific regulation of prolactin function. Rev Reprod 1997;2:14-18.

87 Berlanga JJ, Garcia-Ruiz JP, Perrot-Applanat M, Kelly PA, Edery M: The short form of the prolactin (PRL) receptor silences PRL induction of the beta-casein gene promoter. Mol Endocrinol 1997;11:1449-1457.
88 Anderson GM, Kieser DC, Steyn FJ, Grattan DR: Hypothalamic prolactin receptor messenger ribonucleic acid levels, prolactin signaling, and hyperprolactinemic inhibition of pulsatile luteinizing hormone secretion are dependent on estradiol. Endocrinology 2008; 149:1562-1570.

89 Bowen JM, Telleria CM, Towns R, Keyes PL: Downregulation of long-form prolactin receptor mRNA during prolactin-induced luteal regression. Eur J Endocrinol 2000;143: 285-292.

-90 Shao R, Nutu M, Weijdegard B, Egecioglu E, Fernandez-Rodriguez J, Tallet E, Goffin V, Ling C, Billig H: Differences in prolactin receptor (PRLR) in mouse and human fallopian tubes: evidence for multiple regulatory mechanisms controlling PRLR isoform expression in mice. Biol Reprod 2008;79:748-757.
91 Moldrup A, Petersen ED, Nielsen JH: Effects of sex and pregnancy hormones on growth hormone and prolactin receptor gene expression in insulin-producing cells. Endocrinology 1993;133:1165-1172.

92 Damiano JS, Rendahl KG, Karim C, Embry MG, Ghoddusi M, Holash J, Fanidi A, Abrams TJ, Abraham JA: Neutralization of prolactin receptor function by monoclonal antibody LFA102, a novel potential therapeutic for the treatment of breast cancer. Mol Cancer Ther 2013;12:295-305. 